\title{
Induction of the Platelet Release Reaction
}

\section{by Phytohemagglutinin}

\author{
Douglas M. Tollefsen, John R. Feagler, and Phimip W. Majerus \\ From the Division of Hematology-Oncology, Departments of Internal Medicine \\ and Biochemistry, Washington University School of Medicine, \\ St. Louis, Missouri 63110
}

A в S T R A C T We have previously shown that the erythroagglutinating phytohemagglutinin (E-PHA) from Phaseolus vulgaris binds to the surface of intact human platelets and that adenylate cyclase activity in the particulate fraction of E-PHA-treated platelets is lower than in comparable controls. We now find that E-PHA induces release of $\left[{ }^{14} \mathrm{C}\right]$ serotonin from platelets. Release follows binding of E-PHA, and a haptenic inhibitor of E-PHA binding prevents induction of release. E-PHA does not produce platelet lysis and has little effect on $\left[{ }^{14} \mathrm{C}\right]$ serotonin uptake. Platelets possess approximately 300,000 receptor sites for E-PHA per cell, and we estimate that about $15 \%$ of these sites must be occupied by E-PHA to initiate the release reaction. Prior incubation of platelets with prostaglandin $E_{1}$, theophylline, or dibutyryl cyclic AMP prevents E-PHA-induced release, although these agents have little effect on E-PHA binding to platelets. Thrombin and E-PHA produce different rates and extents of serotonin release. Thrombin (1 $\mathrm{U} / \mathrm{ml}$ ) causes release of $75-85 \%$ of platelet $\left[{ }^{14} \mathrm{C}\right]-$ serotonin, with half-maximal release occurring less than $0.5 \mathrm{~min}$ after thrombin addition. E-PHA, however, induces release of only $30-60 \%$ of platelet serotonin at a 10-fold slower rate. In addition, utilizing electron microscopy, we have observed striking differences in the morphological changes that occur in platelets exposed to E-PHA as compared with thrombin. Thus, the platelet release reaction may be triggered in part by binding of E-PHA to the cell surface, but this reaction only partially resembles that produced by thrombin.

This work has been reported in part, 1973. J. Clin. Invest. 52: $84 a$. (Abstr.)

$\mathrm{Mr}$. Tollefsen was supported by a National Institutes of Health Predoctoral Training Grant GM-1311.

Received for publication 11 June 1973 and in revised form 31 August 1973.

The Journal of Clinical Investigation Volume 53 January 1974·211-218

\section{INTRODUCTION}

Platelet function during hemostasis is characterized by two interrelated processes: $(a)$ aggregation and $(b)$ the "release reaction," in which adenine nucleotides, serotonin, certain proteins, and other compounds are released from the cells (1). Thrombin induces both platelet aggregation and release in suspensions of washed human platelets. The mechanism by which thrombin produces these effects remains unknown, although we have postulated that thrombin acts at the platelet surface to initiate these reactions (2). Previous experiments demonstrated that thrombin inactivates membrane-bound adenylate cyclase when added to intact platelets and that this inactivation is inhibited by preincubation of the cells with agents which elevate cAMP ${ }^{1}$ levels (3). We previously suggested that the substrate for thrombin in the platelet membrane might be the 190,000 dalton glycoprotein designated thrombin-sensitive protein (2). More recent experiments indicate that this protein is released intact from the membrane fraction of the cell after thrombin treatment (4), and, therefore, it is probably not the thrombin substrate. Thus, the mechanism of the thrombin reaction remains obscure.

A variety of other agents, including collagen, ADP, antigen-antibody complexes, venoms, and other proteases produce platelet aggregation and/or the release reaction (1). We have recently reported the binding of several phytohemagglutinins to the platelet plasma membrane and have reported that two of these compounds from Phaseolus vulgaris designated erythroagglutinating phytohemagglutinin (E-PHA) and leukoagglutinating

${ }^{1}$ Abbreviations used in this paper: cAMP, cyclic adenosine $3^{\prime}, 5^{\prime}$-monophosphate; dibutyryl cAMP (DB-cAMP), $\mathrm{N}^{\bullet}-2^{\prime}$-O-dibutyryl cyclic adenosine $3^{\prime}, 5^{\prime}$-monophosphate; $\mathrm{PGE}_{1}$, prostaglandin $\mathrm{E}_{1}$; E-PHA, erythroagglutinating phytohemagglutinin of Phaseolus vulgaris; lentil-PHA, lentil phytohemagglutinin. 
phytohemagglutinin (L-PHA) inhibit adenylate cyclase and induce release of thrombin-sensitive protein after binding to human platelets (5). Since, in contrast to thrombin these phytohemagglutinins presumably have no proteolytic activity, we have attempted to delineate the mechanism and extent of the effects these compounds produce when added to platelets to elucidate further the mechanism of the platelet release reaction. Herein we report experiments that examine the E-PHA-induced release reaction in human platelets.

\section{METHODS}

Materials. E-PHA was purified from Bacto phytohemagglutinin-P (Difco Laboratories, Detroit, Mich.) and labeled with ${ }^{125} \mathrm{I}$ as previously reported (5). Protein concertration was estimated by measuring absorbance at 280 $\mathrm{nm}$, assuming 1.0 absorbance unit $=1 \mathrm{mg} / \mathrm{ml}$ of protein. The molecular weight of E-PHA was assumed to be 128,000 (6). Bovine thrombin was purified from topical thrombin (Parke, Davis \& Company, Detroit, Mich.) by the method of Glover and Shaw (7), which yielded a fibrinogen-clotting activity of $2,000-2,500 \mathrm{NIH} \mathrm{U/mg} \mathrm{of} \mathrm{protein.}$

$\left[{ }^{125} \mathrm{I}\right]$ Sodium iodide was purchased from Mallinckrodt Chemical Works, St. Louis, Mo. Serotonin $\left[2-{ }^{14} \mathrm{C}\right]$ binoxalate $(22.1 \mu \mathrm{Ci} / \mu \mathrm{mol})$ was purchased from New England Nuclear, Boston, Mass.

Dibutyryl cyclic AMP (DB-cAMP) and bovine serum albumin (crystallized and lyophilized) were obtained from Sigma Chemical Co., St. Louis, Mo.

Theophylline was purchased from Mann Research Labs, Inc., New York. Prostaglandin $\mathrm{E}_{1}\left(\mathrm{PGE}_{1}\right)$ was a gift from Dr. John Pike, The Upjohn Co., Kalamazoo, Mich. Fetuin (Spiro method) was purchased from Grand Island Biological Co., Grand Island, N. Y., and was dialyzed overnight against Tris-buffered saline $(\mathrm{pH} \mathrm{7.5)}$ before use.

Millipore filters (RAWP-025-00, $1.2 \mu \mathrm{m}$ pore diameter) were purchased from Millipore Corp., Bedford, Mass.

Isolation of platelets. Platelets were isolated from 60 $70 \mathrm{ml}$ of human blood as follows: Whole blood was placed in $50-\mathrm{ml}$ plastic centrifuge tubes containing $\mathrm{Na}_{2}$ EDTA ( $5 \mathrm{mM}$ final concentration) and centrifuged for $3 \mathrm{~min}$ at $1,400 \mathrm{~g}$. The supernatant platelet-rich plasma was centrifuged at $2,250 \mathrm{~g}$ for $15 \mathrm{~min}$ and the resulting pellet was resuspended in $40 \mathrm{ml}$ of isotonic phosphate-buffered saline ( $\mathrm{pH}$ 6.5) containing $0.113 \mathrm{M} \mathrm{NaCl}, 0.0043 \mathrm{M}$

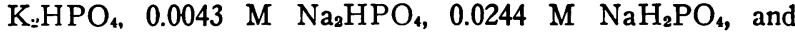
$0.0055 \mathrm{M}$ glucose. The platelet suspension was then centrifuged at $120 \mathrm{~g}$ for $10 \mathrm{~min}$ to remove contaminating leukocytes and erythrocytes. The pellet of erythrocytes and leukocytes was resuspended in phosphate-buffered saline $(\mathrm{pH} 6.5)$ and centrifuged at $120 \mathrm{~g}$ for $10 \mathrm{~min}$ to recover platelets that sedimented in the first $120 \mathrm{~g}$ spin. The platelets were then washed twice in phosphate-buffered saline by centrifugation at $2,250 \mathrm{~g}$ for $15 \mathrm{~min}$ and finally resuspended in isotonic Tris-buffered saline ( $\mathrm{pH} 7.5)$ containing $0.14 \mathrm{M} \mathrm{NaCl}, 0.015 \mathrm{M}$ Tris- $\mathrm{HCl}$, and $0.0055 \mathrm{M}$ glucose at $3-6 \times 10^{\circ}$ platelets $/ \mathrm{ml}$. The platelet concentration was estimated by spinning an aliquot of the final suspension in a microhematocrit centrifuge, assuming that a $1 \%$ packed cell volume equals $10^{\circ}$ cells $/ \mathrm{ml}$. The entire isolation procedure was performed at room temperature, plastic centrifuge tubes and pipettes were used throughout, and subsequent experiments were completed within $8 \mathrm{~h}$ of the time the blood was drawn.
Platelets for electron microscopy were suspended in isotonic cacodylate-buffered saline $(\mathrm{pH}$ 6.8) containing 0.14 $\mathrm{M} \mathrm{NaCl}, 0.015 \mathrm{M}$ sodium cacodylate- $\mathrm{HCl}, 0.0055 \mathrm{M}$ glucose, and $5 \mathrm{mg} / \mathrm{ml}$ bovine serum albumin. Albumin $(5 \mathrm{mg} /$ $\mathrm{ml})$ was also present in the phosphate-buffered saline used to wash these platelets. These modifications had little effect on platelet aggregation or release of serotonin induced by E-PHA or by thrombin.

Incubation of platelets with $\left[{ }^{14} \mathrm{C}\right]$ serotonin. Platelets to be used in serotonin release experiments were suspended in phosphate-buffered saline ( $\mathrm{pH} 6.5)$ at about $10^{8}$ platelets/ $\mathrm{ml}$ and incubated with $4 \mu \mathrm{M}\left[{ }^{14} \mathrm{C}\right]$ serotonin at $37^{\circ}$ for 60-90 min before the two final wash spins (see preceding section). Approximately $75 \%$ of the serotonin added was taken up by the platelets under these conditions.

Binding of E-PHA to platelets. Reaction mixtures containing $0.5 \times 10^{8}$ platelets in $0.5 \mathrm{ml}$ of Tris-buffered saline $\left(\mathrm{pH}\right.$ 7.5) were incubated at room temperature with ${ }^{125} \mathrm{I}$ labeled E-PHA. Additional substances were also present in some cases as indicated below. After a given length of time the incubation was terminated by the addition of $5 \mathrm{ml}$ of ice-cold buffer, and the platelets were collected immediately by filtration through a Millipore filter under reduced pressure. The filter was washed once with $5 \mathrm{ml}$ of cold buffer and counted in a Packard autogamma counter, Packard Instrument Co., Inc., Downers Grove, Ill. Plastic tubes $(12 \times 75 \mathrm{~mm})$ and Millipore filters used in these experiments were soaked in $0.5 \%$ bovine serum albumin for at least $2 \mathrm{~h}$ before use to reduce adsorption of iodinated phytohemagglutinin (5).

Measurement of serotonin release. Incubations were conducted with platelets containing $\left[{ }^{14} \mathrm{C}\right]$ serotonin under conditions similar to those employed in the binding experiments. The incubations were terminated, and the suspensions were filtered as described above. Filters were dissolved in $10 \mathrm{ml}$ of Bray's solution (8) and counted in a Packard Tri-Carb liquid scintillation counter. The amount of $\left[{ }^{14} \mathrm{C}\right]$ serotonin retained in control platelets (no additions) during the course of each experiment reported here varied less than $5 \%$.

Enzyme assays. Lactate dehydrogenase (9) and glucose6-phosphate dehydrogenase (10) were assayed as described previously. Assays were performed on the supernatant fraction after the platelets had been removed by centrifugation at 2,250 g. Alternatively, platelets were disrupted by sonication for $30 \mathrm{~s}$ at $0^{\circ} \mathrm{C}$ using the microprobe of a Biosonik II sonifier (Will Scientific Inc., Rochester, N. Y.) at $50 \%$ intensity, and the supernate was assayed after centrifugation at $48,000 \mathrm{~g}$.

Electron microscopy. Incubations with E-PHA or with thrombin were conducted in $5 \mathrm{ml}$ of cacodylate-buffered saline $(\mathrm{pH} 6.8)$ at $10^{8}$ platelets $/ \mathrm{ml}$. Platelets were fixed by adding an equal volume of $6 \%$ glutaraldehyde with gentle mixing. After $15 \mathrm{~min}$ at room temperature, the platelets were washed three times in cacodylate-buffered saline and post-fixed with $2 \%$ osmium tetroxide. Thereafter standard embedding procedures were followed. Sectioning was done on a Porter-Blum ultramicrotome, model MT-1. A Philips 300 electron microscope (Philips Electronic Instruments, Mount Vernon, N. Y.) was used.

\section{RESULTS}

Response of platelets to E-PHA. The time course of binding of $\left.{ }^{225} \mathrm{I}\right] \mathrm{E}-\mathrm{PHA}$ to platelets is shown in Fig. 1. At an E-PHA concentration of $156 \mathrm{nM}$, half 
maximal binding occurred at about $1 \mathrm{~min}$ after the addition of the lectin, and equilibrium of the binding reaction was attained at $20 \mathrm{~min}$. In addition, Fig. 1 illustrates the E-PHA-induced release of $\left[{ }^{14} \mathrm{C}\right]$ serotonin from platelets. Approximately $50 \%$ of the serotonin was released in $30 \mathrm{~min}$, with half maximal release occurring after $5 \mathrm{~min}$ of incubation with E-PHA. These data indicate that phytohemagglutinin binding precedes the release of serotonin.

Platelets possess approximately 300,000 E-PHA receptor sites per cell as determined in this paper ${ }^{2}$ by the method of Steck and Wallach (11), and we estimate that at the concentration of E-PHA used in the experiment in Fig. 1 (156 nM total) about $90 \%$ of these receptors are occupied at equilibrium.

Higher concentrations of E-PHA produce no further serotonin release as indicated in Fig. 2. However, at E-PHA concentrations below about $40 \mathrm{nM}$, the amount of serotonin released in $60 \mathrm{~min}$ is decreased. Below about $5 \mathrm{nM}$ E-PHA little if any serotonin is released from platelets in a $60 \mathrm{~min}$ incubation.

We have correlated serotonin release with the percentage of total E-PHA receptor sites that have E-PHA bound to them (Fig. 2). Equilibrium of binding was attained within $20 \mathrm{~min}$ at each level of E-PHA tested. Maximal serotonin release is observed when $50 \%$ of E-PHA receptors are occupied by E-PHA. On the other hand, about $5-15 \%$ of the receptors must bind E-PHA in order for any measurable release to occur within a $60 \mathrm{~min}$ incubation period. Half maximal release occurs when approximately $25 \%$ of the E-PHA receptors are occupied. Time course experiments at low concentrations of E-PHA $(<40 \mathrm{nM})$ indicate that the release of serotonin continues beyond $60 \mathrm{~min}$ at a very low rate. It is therefore impossible to conclude from these data whether the degree of E-PHA binding affects both the rate and the maximum extent of release or the rate of release only.

The glycoprotein fetuin is a haptenic inhibitor of EPHA binding to platelets (5). Fetuin should therefore prevent E-PHA induction of serotonin release if this process depends upon E-PHA binding to platelets. Addition of fetuin at a final concentration of $0.22 \mathrm{mM}(10$ $\mathrm{mg} / \mathrm{ml}$ ) reduced the binding of E-PHA by $91 \%$ and

${ }^{2}$ The number of E-PH.A receptor sites per platelet differs slightly from that previously reported $(500,000-600,000$ [5]). This difference is probably due to a variety of factors including the method of counting the platelets. In this work we estimated platelet concentration by the microhematocrit method, whereas before platelets were counted directly. Furthermore, the E-PHA used in these experiments was purified from a different lot of Difco phytohemagglutinin-P. Differences of $10-30 \%$ are seen using different platelet preparations although results obtained using a single preparation are highly reproducible $( \pm 5$ $10 \%)$.

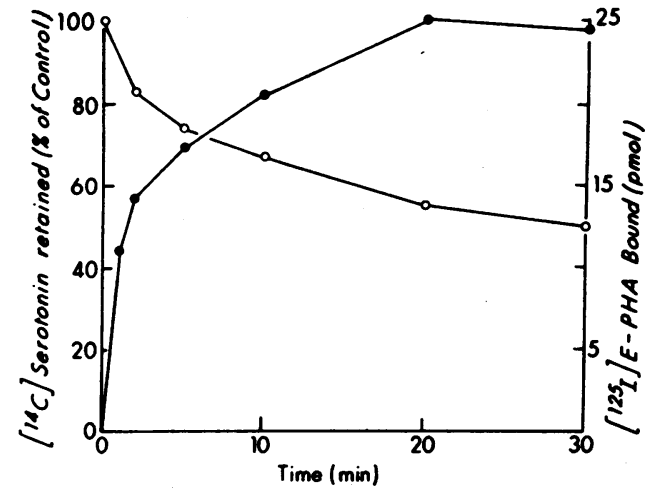

Figure 1 Time course of $\left[{ }^{12} \mathrm{I}\right] \mathrm{E}-\mathrm{PHA}$ binding to platelets and release of $\left[{ }^{14} \mathrm{C}\right]$ serotonin. Each point represents a separate incubation containing $0.5 \times 10^{8}$ platelets in 0.5 $\mathrm{ml}$ Tris-buffered saline ( $\mathrm{pH} 7.5)$. Incubations were started by addition of E-PHA (156 nM total concentration) and terminated by filtration as described in Methods. All incubations were conducted at room temperature. $-\bullet$, binding of ${ }^{125}$ I-labeled E-PHA $(5,020 \mathrm{cpm} / \mathrm{pmol})$. $\bigcirc-O$, release of $\left[{ }^{14} \mathrm{C}\right]$ serotonin from platelets induced by unlabeled E-PHA (control $=42,000 \mathrm{cpm} / 10^{8}$ platelets).

prevented the release of serotonin (Table I). To exclude the possible presence in the E-PHA preparation of a contaminating proteolytic enzyme, which could itself induce the release of serotonin and which might be competitively inhibited by such a high concentration of protein $(10 \mathrm{mg} / \mathrm{ml})$, the experiment was repeated with the addition of albumin $(10 \mathrm{mg} / \mathrm{ml})$ in place of fetuin. As shown in Table I, albumin inhibited neither

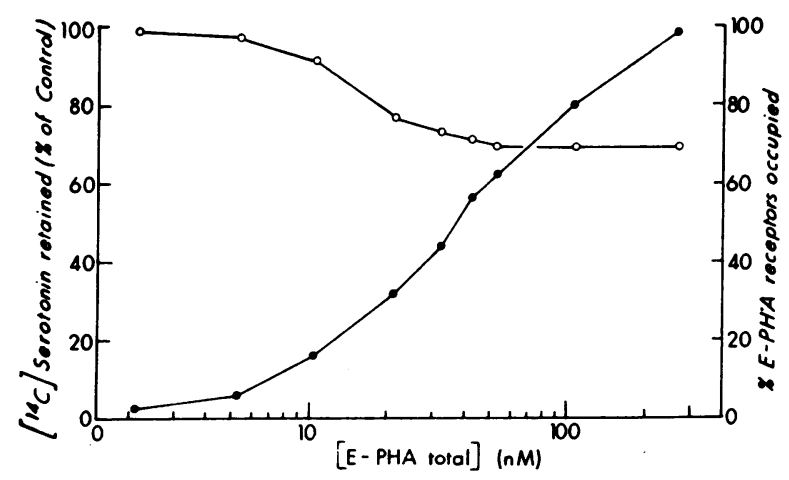

FIgURE 2 Degree of E-PHA binding to platelet receptors and the release of $\left[{ }^{14} \mathrm{C}\right]$ serotonin. Incubations were conducted as in Fig. 1 for $60 \mathrm{~min}$ after addition of E-PHA ( ${ }^{12}$ I-labeled or unlabeled) at the concentrations indicated. [E-PHA total] is the total concentration of E-PHA added to each incubation and therefore represents the sum of [E-PHA bound] and [E-PHA free]. The percentage of E-PHA receptors occupied was calculated by dividing the amount of $\left[{ }^{125} \mathrm{I}\right] \mathrm{E}-\mathrm{PHA}$ bound by the amount bound at saturation, which was determined from these data as in Fig. 3. $\bigcirc-O$, release of $\left[{ }^{14} \mathrm{C}\right]$ serotonin. $-\longrightarrow$, percent E-PHA receptors occupied.

Platelet Release by Phytohemagglutinin 
TABLE I

Effect of Fetuin and Albumin on E-PHA Binding to Platelets and on Release of $\left[{ }^{14} \mathrm{C}\right]$ Serotonin Induced by E-PHA and Thrombin

\begin{tabular}{lcc}
\hline \multicolumn{1}{c}{ Additions } & $\begin{array}{c}\text { E-PHA } \\
\text { bound }\end{array}$ & $\begin{array}{c}{[14 \mathrm{C}] \text { Serotonin }} \\
\text { retained } \\
\text { (\% of control) }\end{array}$ \\
\hline & pmol & \\
None & 16.9 & 100 \\
E-PHA (total concentration $39 \mathrm{nM})$ & 1.46 & 100 \\
E-PHA (39 $\mathrm{nM})+$ fetuin $(10 \mathrm{mg} / \mathrm{ml})$ & 14.8 & 74 \\
E-PHA (39 $\mathrm{nM})+$ albumin $(10 \mathrm{mg} / \mathrm{ml})$ & & 24 \\
Thrombin $(0.5 \mathrm{U} / \mathrm{ml})$ & & 27 \\
Thrombin $(0.5 \mathrm{U} / \mathrm{ml})+$ fetuin $(10 \mathrm{mg} / \mathrm{ml})$ & 30 \\
Thrombin $(0.5 \mathrm{U} / \mathrm{ml})+$ albumin $(10 \mathrm{mg} / \mathrm{ml})$ & & \\
\hline
\end{tabular}

Platelets $\left(0.5 \times 10^{8}\right)$ were incubated for $30 \mathrm{~min}$ at room temperature in $0.5 \mathrm{ml}$ Tris-buffered saline ( $\mathrm{pH} 7.5$ ). Additional compounds were added at the beginning of each incubation at the final concentrations indicated. Incubations were terminated by filtration (see Methods).

E-PHA binding nor serotonin release. Furthermore, the thrombin-induced release of serotonin is not prevented by either fetuin or by albumin. We conclude that E-PHA binding is essential for E-PHA induction of the release reaction, since the haptenic inhibitor of binding used in these experiments prevents E-PHA-induced release but does not interfere substantially with release when induced by thrombin.

The supernatant fraction from a suspension of platelets incubated with E-PHA was assayed for two intracellular enzymes, lactate dehydrogenase and glucose-6-phosphate dehydrogenase, as a test for cell lysis. Lactate dehydrogenase activity in the supernate was 16 nmol $\mathrm{NAD}^{+}$formed $/ \mathrm{min} / \mathrm{ml}$ after a $2 \mathrm{~h}$ incubation of platelets $\left(10^{8} \mathrm{cells} / \mathrm{ml}\right)$ with E-PHA (50 nM), compared with $14 \mathrm{nmol} / \mathrm{min} / \mathrm{ml}$ in control suspensions (no E-PHA) and $125 \mathrm{nmol} / \mathrm{min} / \mathrm{ml}$ after lysis of the cells by sonication. Glucose-6-phosphate dehydrogenase activity was not detectable in the supernate after a $1 \mathrm{~h}$ incu-

TABLE II

Effect of Theophylline, DB-cAMP, and $P G E_{1}$ on E-PHAInduced Release of $\left[{ }^{14} \mathrm{C}\right]$ Serotonin from Platelets

\begin{tabular}{lc}
\hline \multicolumn{1}{c}{ Additions } & $\begin{array}{c}{\left[{ }^{14} \mathrm{C}\right] \text { Serotonin }} \\
\text { retained } \\
\text { (\% of control })\end{array}$ \\
\hline None & 100 \\
E-PHA (total concentration $78 \mathrm{nM})$ & 42 \\
E-PHA (78 $\mathrm{nM})+$ theophylline $(5 \mathrm{mM}, 3 \mathrm{~min})$ & 96 \\
E-PHA (78 $\mathrm{nM})+$ DB-cAMP $(3 \mathrm{mM}, 3 \mathrm{~min})$ & 78 \\
E-PHA (78 $\mathrm{nM})+$ DB-cAMP $(3 \mathrm{mM}, 30 \mathrm{~min})$ & 94 \\
E-PHA (78 $\mathrm{nM})+$ PGE $_{1}(3 \mu \mathrm{M}, 3 \mathrm{~min})$ & 61 \\
E-PHA $(78 \mathrm{nM})+$ PGE $_{1}(3 \mu \mathrm{M}, 30 \mathrm{~min})$ & 94 \\
\hline
\end{tabular}

Platelets were incubated for $30 \mathrm{~min}$ after the addition of E-PHA as in Table I. Other compounds were added 3 or $30 \mathrm{~min}$ before E-PHA as indicated. bation with E-PHA or in control supernates, while an activity of $13 \mathrm{nmol} \mathrm{NADPH}$ formed $/ \mathrm{min} / \mathrm{ml}$ was present after sonication. These results indicate that E-PHAinduced serotonin release is not a consequence of cell lysis.

It might also be possible for E-PHA to cause net loss of serotonin from platelets by inhibiting the reuptake of serotonin lost from the cells by passive leakage (12). We find that the rate of $\left[{ }^{14} \mathrm{C}\right]$ serotonin uptake is about 25-fold lower under conditions used to study release (see Methods) than under conditions employed in labeling the cells initially, which may be due in part to the lower temperature at which release experiments are performed. We also find that E-PHA has no effect on serotonin uptake under the former conditions. Thus, inhibition of serotonin uptake is not a factor in the observed net loss of serotonin from platelets after EPHA treatment.

Effects of $P G E_{1}$, theophylline, and $D B-c A M P$. Since we have shown that E-PHA decreases adenylate cyclase activity in platelets (3), we were interested in determining whether agents that raise intracellular cAMP levels would inhibit E-PHA-induced release of serotonin. The data in Table II show that almost complete inhibition of release is obtained by incubating platelets with theophylline $(5 \mathrm{mM})$ for $3 \mathrm{~min}$ before the addition of $\mathrm{E}$ -

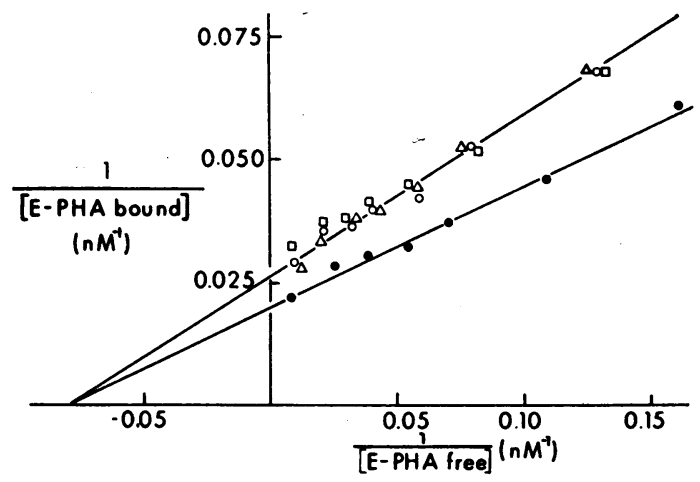

Figure 3 Binding of [125I]E-PHA to platelets in the presence of theophylline, DB-cAMP, or $\mathrm{PGE}_{1}$. Incubations were conducted as in Fig. 1 for $30 \mathrm{~min}$ after addition of E-PHA (total concentration 23-154 nM). Data are plotted according to the method of Steck and Wallach (11). [E-PHA free] was calculated by subtracting [EPHA bound] from [E-PHA total]. The intercept on the ordinate equals $1 /[\mathrm{E}-\mathrm{PHA}$ bound $]$ at saturation. The number of E-PHA receptors per platelet is found by dividing [E-PHA bound] at saturation by the platelet concentration $\left(10^{8}\right.$ platelets $\left./ \mathrm{ml}\right)$. The intercept on the abscissa equals $-1 / \mathrm{K}_{\mathrm{d} \text { ss }}$ of the E-PHA-receptor complex. - - , binding of $\left[{ }^{120} \mathrm{I}\right] \mathrm{E}-\mathrm{PHA}$ to platelets (no other additions). $\triangle \longrightarrow \triangle$, platelets incubated with $5 \mathrm{mM}$ theophylline for $3 \mathrm{~min}$ before addition of [ $\left.{ }^{125} \mathrm{I}\right] \mathrm{E}-\mathrm{PHA}$. $\mathrm{O}-\mathrm{O}, 3 \mathrm{mM}$ DB-cAMP, $30 \mathrm{~min} . \square \square, 3 \mu \mathrm{M}$ $\mathrm{PGE}_{1}, 30 \mathrm{~min}$. 
PHA. Inhibition to an equal extent is observed when DB-cAMP $(3 \mathrm{mM})$ or PGE $(3 \mu \mathrm{M})$ is present for 30 min before E-PHA addition. These agents do not alter $\left[{ }^{14} \mathrm{C}\right]$ serotonin uptake when platelets are incubated in Tris-buffered saline $(\mathrm{pH} 7.5)$ at room temperature.

The effect of these agents on the binding of E-PHA to platelets is shown in Fig. 3. The data indicate that in the absence of these agents platelets possess about 300,000 receptor sites per cell for E-PHA which binds with an apparent dissociation constant of $13 \mathrm{nM}$. Preincubation of platelets with DB-cAMP, $\mathrm{PGE}_{1}$ or theophylline apparently decreases the number of E-PHA receptor sites to about 240,000 per platelet without affecting the time course or the affinity of binding. Thus, while these compounds inhibit serotonin release, they do not prevent E-PHA binding.

Kinetics of $\left[{ }^{14} \mathrm{C}\right]$ serotonin release induced by E-PHA and by thrombin. The maximum extent of serotonin release induced by E-PHA varies between 30 and $60 \%$ with different platelet preparations (see Figs. 1, 2 , and 4$)$. In contrast, thrombin consistently induces the release of $75-85 \%$ of platelet serotonin. We present a comparison of the kinetics of serotonin release induced by E-PHA and by thrombin using a single platelet preparation in Fig. 4. The concentrations of both E-PHA $(256 \mathrm{nM})$ and thrombin $(1 \mathrm{U} / \mathrm{ml})$ were sufficient to produce the maximum obtainable response in this platelet preparation. E-PHA differs from thrombin both in the extent and in the rate of serotonin release. In this experiment the extent of release is $56 \%$ for E-PHA and $81 \%$ for thrombin. The half time of thrombininduced release is less than $0.5 \mathrm{~min}$, while for E-PHA it is about $7.5 \mathrm{~min}$. In addition, Fig. 4 shows the effect of thrombin on platelets which are nearly saturated with E-PHA molecules and which have undergone E-PHAinduced release of serotonin. Thrombin is capable of releasing additional serotonin, although the rate of release is somewhat less than that observed with thrombin alone. The total amount of serotonin released by E-PHA followed by thrombin is equal to the amount released by thrombin alone.

Morphological changes in platelets incubated with $E$ PHA and with thrombin. Although E-PHA and thrombin can each initiate the platelet release reaction, the experiments described above indicate that the effects of these two compounds differ with respect to the maximum extent of release and the rate of release of serotonin. To investigate further the effects produced by E-PHA and thrombin, we have utilized the technique of electron microscopy.

Control platelets (Figs. $5 a$ and $5 b$ ) isolated by our techniques are similar in shape and ultrastructural detail to those described by others (13). Such platelets are disk-shaped and are usually without pseudopods. The

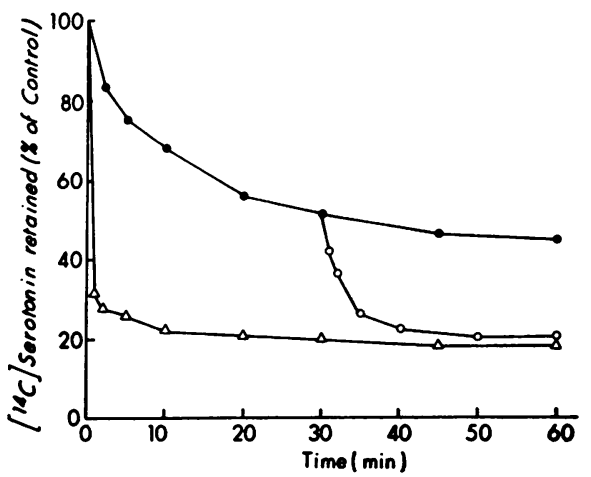

FIgURE 4 Release of $\left[{ }^{14} \mathrm{C}\right]$ serotonin from platelets induced by E-PHA and thrombin. Incubations were conducted as in Fig. 1. - - E-PHA (total concentration $156 \mathrm{nM}$ ). $\triangle \longrightarrow \triangle$, thrombin $(1 \mathrm{U} / \mathrm{ml})$. O-O, thrombin (1 U/ $\mathrm{ml}$ ) added after $30 \mathrm{~min}$ of incubation with E-PHA (156 $\mathrm{nM})$.

canalicular system is prominent, with channels extending throughout the platelet. Granules are readily identified and microtubules are frequently seen (in cross section or sectioned longitudinally) in a circumferential band near the cytoplasmic membrane.

Platelets treated with thrombin $(2 \mathrm{U} / \mathrm{ml}, 2 \mathrm{~min}$ before fixation) become spherical with central movement of the peripheral microtubular system and develop many elongated pseudopods (Fig. 5c). Degranulation occurs uniformly and is nearly complete in all platelets. Reorganization of the canalicular system occurs with the formation of a dense conglomerate of amorphous material at the center of the platelet. Microtubules and microfilaments are frequently associated with this material.

E-PHA-treated platelets (413 $\mathrm{nM}, 30 \mathrm{~min}$ before fixation) also become spherical with loss of peripheral microtubules, but in contrast with thrombin-treated platelets, they form few elongated pseudopods (Fig. 5d). Degranulation occurs less uniformly than in thrombintreated platelets, although nearly all of the platelets become degranulated to some extent. The canalicular system reorganizes, forming a system of thin, coiled channels, but it does not become densely packed at the center of the cell as in thrombin-treated platelets. Very few microtubules are seen in the cytoplasm of E-PHAtreated platelets. In other experiments we have observed that E-PHA reverses pseudopod formation in thrombintreated platelets.

\section{DISCUSSION}

Our observation that E-PHA induces the release of serotonin from platelets suggests that a membrane glycoprotein might be involved in induction of the platelet release reaction. This suggestion follows from several lines 


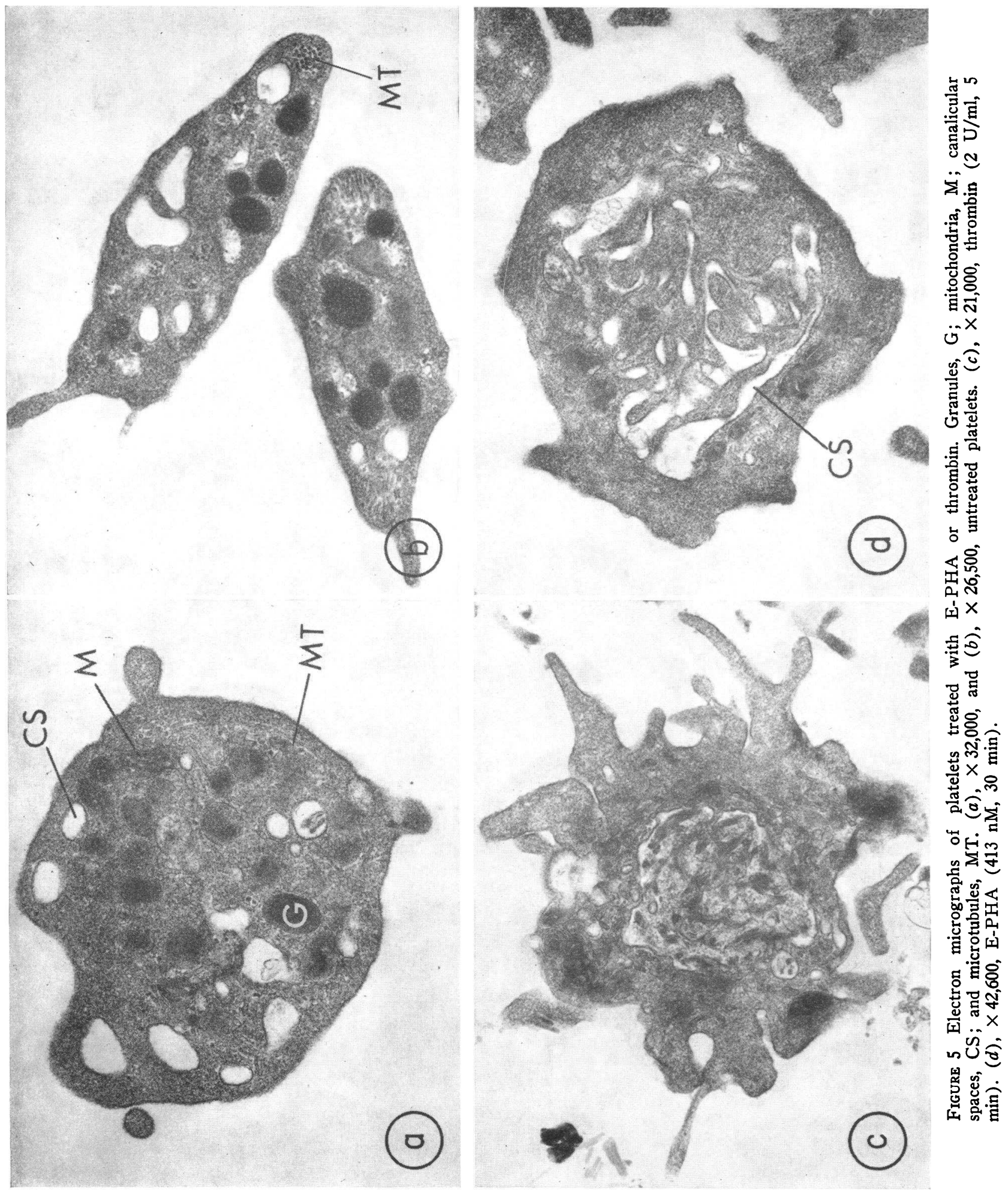

216 D. M. Tollefsen, J. R. Feagler, and P. W. Majerus 
of evidence. In the first place, Kornfeld and Kornfeld have demonstrated that the E-PHA receptor site on erythrocytes is carbohydrate in nature, and they have determined the structure of the receptor oligosaccharide (14). It is reasonable to assume that the E-PHA receptor of platelets has a similar structure. Secondly, we have shown that E-PHA bound to platelets can be removed by certain oligosaccharide haptenic inhibitors, indicating that E-PHA remains at the outer surface of the platelet ${ }^{8}$ and is not transported into the cell (5). Thirdly, kinetic experiments indicate that release of serotonin from platelets is subsequent to the binding of E-PHA (Fig. 1). Moreover, fetuin, a glycoprotein that inhibits E-PHA binding to platelets, prevents the induction by E-PHA of serotonin release (Table I). Finally, several experiments suggest that E-PHA-induced release does not occur by an unusual mechanism. We have shown that E-PHA has little effect on serotonin uptake into platelets and does not cause platelet lysis. In addition, E-PHA induction of release appears to be correlated with inhibition of adenylate cyclase in a manner analogous to that observed with other release inducers (see below). We conclude that the binding of E-PHA to a receptor site, probably a glycoprotein, on the platelet surface initiates the release reaction. We have no evidence, however, to implicate a membrane glycoprotein in release induced by other agents.

Membrane-bound adenylate cyclase has been implicated in induction of the platelet release reaction. Adenylate cyclase activity in the particulate fraction of thrombin-treated platelets is decreased by $60-80 \%$ within $30 \mathrm{~s}$ (3). PGE 1 and other substances that presumably increase the level of intracellular cAMP prevent this inhibition of adenylate cyclase by thrombin, and these agents have been shown to inhibit the thrombin-induced release of calcium (15), adenine nucleotides (15), and thrombin-sensitive protein (3). We previously demonstrated that adenylate cyclase activity in the particulate fraction of E-PHA-treated platelets is lower than in untreated controls (5), and our present results indicate that preincubation of platelets with $\mathrm{PGE}_{1}, \mathrm{DB}-\mathrm{cAMP}$, or theophylline inhibits the release of serotonin induced by E-PHA (Table II). Experiments with E-PHA thus provide further evidence that inhibition of adenylate cyclase is part of the platelet release reaction. The possible interaction between the E-PHA receptor and adenylate cyclase requires further study.

Platelets possess a large number of high affinity receptor sites for lentil-PHA (5) as well as for E-PHA. Lentil-PHA, however, does not cause inhibition of platelet adenylate cyclase (5) nor does it induce the

\footnotetext{
'We have not excluded the possibility that a very small amount of E-PHA enters the cell.
}

release of serotonin at levels sufficient to saturate the platelet receptor sites." Furthermore, lentil-PHA does not interfere with the release reaction induced by $\mathrm{E}$ $\mathrm{PHA}$ or by thrombin. It is interesting that lentil-PHA and E-PHA bind to different parts of a single glycopeptide in the erythrocyte membrane (16).

Previous studies have suggested that the release reaction is accompanied by conformational changes in the platelet plasma membrane. We have found that thrombin produces an apparent twofold increase in the number of receptor sites available for lentil-PHA binding on the platelet surface (5). In addition, thrombin causes the release from platelet membranes of a 190,000 dalton glycoprotein designated thrombin-sensitive protein (2, $4)$. We do not know whether these changes occur as an immediate result of the action of thrombin or at some later stage in the release process. In the present work we have obtained indirect evidence suggesting that the release reaction is also accompanied by changes in the number of E-PHA receptor sites available for binding. When we performed studies to determine the effect of inhibitors of the release reaction on E-PHA binding (Fig. 3), the number of E-PHA receptor sites appeared to be about $25 \%$ greater in the absence than in the presence of these inhibitors. ${ }^{5}$ The concentrations (23$154 \mathrm{nM}$ ) of E-PHA used in these binding studies were sufficient to produce maximal release of serotonin in the absence of inhibitors (see Fig. 2). Thus, it appears that the number of E-PHA receptor sites increases during the release reaction.

We have observed several differences in the effects of E-PHA and thrombin on platelets. Both the rate and the extent of release produced by E-PHA are less than those produced by thrombin (Fig. 4). In addition, EPHA does not cause platelet pseudopod formation, nor does it cause central movement of the canalicular system and other organelles (Fig. 5). These morphological changes are seen in platelets treated with thrombin (Fig. 5), and the rearrangement of the protein subunits of microtubules or microfilaments is thought to be associated with these processes (13). These differences might be related to the fact that thrombin is a proteolytic enzyme, whereas E-PHA has no known proteolytic activity. Thus, it appears that E-PHA is capable of activating only a portion of the release reaction (i.e., that which is mediated by cAMP). E-PHA might therefore be a useful tool in further studies designed to elucidate the platelet release reaction.

\footnotetext{
‘Tollefsen, D. M., and P. W. Majerus. Unpublished observations.

'It is highly unlikely that the three inhibitors tested, which are structurally unrelated, could each directly interfere with E-PHA binding.
} 


\section{ACKNOWLEDGMENTS}

We wish to thank Nancy Stanford for her excellent technical assistance.

This research was supported by grants AM 10550 and HE 14147 from the National Institutes of Health and by grant PRA 33 from the American Cancer Society.

\section{REFERENCES}

1. Holmsen, H., H. J. Day, and H. Stormorken. 1969. The blood platelet release reaction. Scand. J. Haematol. Suppl. 8: 1 .

2. Baenziger, N. L., G. N. Brodie, and P. W. Majerus. 1971. A thrombin-sensitive protein of human platelet membranes. Proc. Natl. Acad. Sci. U. S. A. 68: 240.

3. Brodie, G. N., N. L. Baenziger, L. R. Chase, and P. W. Majerus. 1972. The effects of thrombin on adenyl cyclase activity and a membrane protein from human platelets. J. Clin. Invest. 51: 81.

4. Baenziger, N. L., G. N. Brodie, and P. W. Majerus. 1972. Isolation and properties of a thrombin-sensitive protein of human platelets. J. Biol. Chem. 247: 2723.

5. Majerus, P. W., and G. N. Brodie. 1972. The binding of phytohemagglutinins to human platelet plasma membranes. J. Biol. Chem. 247: 4253.

6. Weber, T., C. T. Nordman, and R. Gräsbeck. 1967. Separation of lymphocyte-stimulating and agglutinating activities in phytohemagglutinin (PHA) from Phaseolus vulgaris. Scand. J. Haematol. 4: 77.

7. Glover, G., and E. Shaw. 1971. The purification of thrombin and isolation of a peptide containing the active center histidine. J. Biol. Chem. 246: 4594.

8. Bray, G. A. 1960. A simple efficient liquid scintillator for counting aqueous solutions in a liquid scintillation counter. Anal. Biochem. 1: 279.

9. Wroblewski, F., and J. S. LaDue. 1955. Lactic dehydrogenase activity in blood. Proc. Soc. Exp. Biol. Med. $90: 210$.

10. Majerus, P. W., M. B. Smith, and G. H. Clamon. 1969. Lipid metabolism in human platelets. I. Evidence for a complete fatty acid synthesizing system. J. Clin. Invest. 48: 156

11. Steck, T. L., and D. F. H. Wallach. 1965. The binding of kidney-bean phytohemagglutinin by Ehrlich ascites carcinoma. Biochem. Biophys. Acta. 97: 510.

12. Okuda, M., and Y. Nemerson. 1971. Transport of serotonin by blood platelets: a pump-leak system. Am. J. Physiol. 220: 283.

13. White, J. G. 1971. Platelet morphology. In The Circulating Platelet. S. A. Johnson, editor. Academic Press, Inc., New York. 46.

14. Kornield, R., and S. Kornfeld. 1970. The structure of a phytohemagglutinin receptor site from human erythrocytes. J. Biol. Chem. $245: 2536$.

15. Wolfe, S. M., and N. R. Shulman. 1970. Inhibition of platelet energy production and release reaction by $\mathrm{PGE}_{1}$, theophylline and cAMP. Biochem. Biophys. Res. Commun. $41: 128$.

16. Kornfeld, S., J. Rogers, and W. Gregory. 1971. The nature of the cell surface receptor site for Lens culinaris phytohemagglutinin. J. Biol. Chem. 246: 6581. 